Tekst został przetłumaczony na podstawie: G. Sorel, Réflexions sur la violence, Paris 1908, s. $122-134$.

\title{
Moralność przemocy
}

\section{I}

W szelkie kodeksy podejmują wszystkie możliwe środki ostrożności, mające na celu przeciwdziałanie przemocy, zaś edukacją kieruje się tak, by łagodzić nasze skłonności do okrucieństwa. Prowadzi nas to do stwierdzenia, że każdy akt przemocy stanowi przejaw regresu w stronę barbarzyństwa. Porównując społeczeństwa industrialne i zmilitaryzowane, to właśnie pokój uznaje się za prymarne z dóbr i warunek niezbędny wszelkiego postępu. Ten punkt widzenia wyjaśnia, dlaczego od XVIII stulecia niemal bez przerwy ekonomiści byli zwolennikami silnej władzy, dbającej o zachowanie wolności politycznych. Condorcet wyrzuca to uczniom Quesnaya, a Napoleon III nie wydawał się większym admiratorem owej idei niż Michel Chevalier.

Możemy zastanawiać się, czy współczesne uwielbienie dla łagodności nie jest w pewnym sensie głupotą. Widzimy bowiem, iż niektórzy autorzy, znani ze swej przenikliwości i wysokich kompetencji moralnych, nie wydają się obawiać przemocy, tak jak dzieje się to w przypadku profesorów.

Tym, co niezwykle uderzyło P. Bureau, było spotkanie w Norwegii głęboko chrześcijańskiej wiejskiej społeczności. Mężczyźni będący jej członkami nosili przy paskach sztylety; kiedy sprzeczka kończyła się wymianą ciosów nożem, śledztwo policji nie ustawało, o ile nie brakowało świadków.

Któregoś dnia Michel Chevalier wkroczył, promieniejąc, do sali kolegium redakcyjnego „Journal des Débats”: ,Jego pierwszymi słowami były: Osiągnąłem wolność! Byliśmy pełni oczekiwania, zażądaliśmy wyjaśnień. Chodziło o wolność rzeźników" (E. Renan, Feuilles détechées, Paris 1892, s. 149). 
Autor wysnuwa taki oto wniosek: „Słaby i zniewieściały charakter mężczyzn jest groźniejszy niż ich - nawet wyolbrzymione i brutalne - poczucie niezależności. Cios zadany nożem przez człowieka - choćby okrutnego, lecz wiernego swym obyczajom - stanowi ze społecznego punktu widzenia zło mniejsze i łatwiejsze do zadośćuczynienia niźli życie w rozpustnych luksusach, wiedzione przez młodzież uważaną za lepiej wychowaną"."

Przytoczę także przykład P. de Rousiers'a, będącego, tak jak i P. Bure$\mathrm{au}$, zagorzałym katolikiem o nienagannej kondycji moralnej. Opowiada on, jak około roku 1860 w okolicach Denver zwierzchnik górników w Górach Skalistych został napadnięty i ograbiony przez bandytów. Amerykańskie władze były bezradne, zaś odważni obywatele wzięli sprawy w swoje ręce: „Prawo Lyncha było częstokroć stosowane; człowiek oskarżony o morderstwo lub rabunek mógł zostać zatrzymany, osądzony, skazany i zawisnąć w czasie krótszym niż pół godziny, jeśli tylko zajął się nim komitet porządkowy. Prawy Amerykanin posiada doskonałą zdolność do tego, by nie dać się zmiażdżyć jedynie z powodu swej prawości; człowiek miłujący ład nie musi być tchórzem, jak zbyt często zdarza się wśród nas. Przeciwnie - uznaje on, że jego interes musi górować nad interesem kuglarza lub tego, który zbiegł wymiarowi sprawiedliwości. Co więcej, ma on energię niezbędną, by oprzeć się pokusom, a jego styl życia także pozwala mu wytrwale im się opierać oraz wychodzić z inicjatywą, jak też przyjmować konsekwencje, jakkolwiek ciężkie by były, jeśli zachodzi taka potrzeba. Taki człowiek, znalazłszy się w nowym kraju, pełnym wszelkich dóbr, chcący korzystać z ukrytych w nim bogactw i przez swą pracę podnieść zajmowaną pozycję, nie zawaha się przed wyeliminowaniem, w imię wyższych racji, które reprezentuje, złoczyńców zagrażających przyszłości tego kraju. Oto dlaczego tyle ciał unosiło się na rzece Denver dwadzieścia pięć lat temu pod niewielkim drewnianym mostem przerzuconym nad Cherry-Creck ${ }^{3}$ ".

U P. de Rousiers'a znajdujemy tę przemyślaną opinię; powraca on również do następującej kwestii: „Powiadam - pisze - że prawo Lyncha jest we Francji powszechnie uważane za oznakę barbarzyństwa...; lecz jeśli prawi Europejczycy myślą w tenże sposób, prawi Amerykanie myślą dokładnie odwrotnie $^{4}$ ". W pełni popiera on komitet porządkowy Nowego Orleanu, który w 1890 r. doprowadził - „ku wielkiej satysfakcji ludzi uczciwych” - do powieszenia członków szajki, skazanych przez ławę przysięgłych ${ }^{5}$.

P. Bureau, Le paysan des fiords de Norvège, Paris 1906, s. 114, 115.

P. de Rousiers, La vie américaine: Ranches, fermes et usines, Paris 1899, s. 224-225.

Tenże, La vie américaine: L'éducation et la société, Paris 1899, s. 218.

Tamże, s. 221. 
Nie wydaje się, by w czasach, w których vendettę regularnie stosowano na Korsyce, uzupełniając lub korygując działania zbyt opieszałego wymiaru sprawiedliwości, poczucie moralności wśród mieszkańców było niższe niż dziś. Przed francuskim podbojem w Kabylii nie znano innego sposobu wymierzania sprawiedliwości niż osobista zemsta, a mieszkańcy regionu nie byli ludźmi złymi.

Przyznamy zwolennikom łagodności, że przemoc może zakłócać rozwój ekonomiczny, a nawet zagrażać moralności, o ile przekracza pewną granicę. Zgoda ta nie może jednak zostać przeciwstawiona wyłożonej tu doktrynie, ponieważ rozważam kwestię przemocy wyłącznie z punktu widzenia jej konsekwencji ideologicznych. Pewne jest zatem, że do skłonienia robotników, by postrzegali konflikty ekonomiczne jako rozmyte obrazy wielkiej bitwy, decydującej o przyszłości, nie są niezbędne eskalacja przemocy i rozlew krwi. Jeśli klasa kapitalistyczna jest silna, ogłasza natychmiast wolę obrony swego stanowiska; jej postawa - szczerze i wiernie reakcyjna - wnosi wkład, nie mniejszy niż przemoc proletariatu, w zaznaczenie rozłamu klasowego, leżącego u podstaw wszelkiego socjalizmu.

Moglibyśmy tu wykorzystać obszerne świadectwa historyczne, których dostarczają prześladowania doświadczane przez chrześcijan w pierwszych wiekach. Współcześni autorzy byli poruszeni językiem ojców Kościoła oraz szczegółami podawanymi w świadectwach męczenników, reprezentowanych głównie przez wypędzonych, których krew płynęła obficie a bezustannie. Tu rozłam zaznaczył się szczególnie wyraźnie między światem pogańskim a chrześcijańskim; bez owego podziału ci ostatni nigdy nie byliby w stanie osiągnąć pełni swej osobowości, lecz zarazem rozróżnienie to nie mogłoby zaistnieć, gdyby sprawy rzeczywiście przybrały obrót, który ongiś uznawaliśmy za prawdziwy.

Nikt nie wierzy już w to, że chrześcijanie ukrywali się w podziemnych kamieniołomach, aby ujść poszukiwaniom. Katakumby zostały wykute za ogromne sumy - przez gminy dysponujące znacznymi środkami - pod powierzchnią ziem należących głównie do możnych rodzin, sprawujących pieczę nad wyznawcami nowego kultu. Nikt nie poddaje już w wątpliwość tego, że przed końcem pierwszego stulecia chrześcijaństwo znalazło zwolenników wśród arystokracji z królewskich rodów; „w bardzo starych katakumbach Pryscylli odnaleźliśmy grobowiec rodziny pochowanej między I a IV wiekiem, pochodzącej z chrześcijańskiej gałęzi rodu Acyliuszy" ${ }^{\prime 6}$. Wydaje się, że należy również porzucić dawne przekonanie dotyczące znacznej liczby męczenników.

P. Allard, Dix leçons sur le martyre, Paris 1905, s. 171. 
Renan utrzymywał, że literaturę traktującą o męczennikach należy brać poważnie: „Szczegóły aktów męczeństwa - pisał - mogą wydawać się w znacznej części fałszywe. Przerażający obraz, jaki przedstawia się naszym oczom, jest rzeczywisty. Częstokroć tworzyliśmy fałszywe wyobrażenia tej strasznej walki, lecz nie wyolbrzymialiśmy ich znaczenia" ${ }^{7}$. Badania Harnacka prowadzą do zgoła odmiennych wniosków - proporcje między językiem autorów chrześcijańskich a rzeczywistą wagą prześladowań są w istotny sposób zachwiane, a samych męczenników przed III wiekiem było bardzo niewielu. Pisarzem, który najsilniej oddawał przerażenie, jakie wyznawcy nowej religii odczuwali przed prześladowcami, był Tertulian. Oto co pisze Harnack: "Jedno spojrzenie rzucone, dzięki dziełom Tertuliana, na Kartaginę i Afrykę Północną wskazuje, że przed 180 rokiem nie było w tym regionie ani jednego męczennika, zaś od tego czasu aż do śmierci Tertuliana (po roku 220) nie naliczono ich wielu więcej niż dwa tuziny, nawet wliczając obszary Numidii i Mauretanii”" Należy wziąć pod uwagę to, że w owym czasie żyli w Afryce liczni montaniści, znacznie wyolbrzymiający chwałę męczenników, zaś milczący o możliwości ujścia prześladowcom.

P. Allard obalił tezę Harnacka za pomocą argumentów, które wydają mi się raczej słabe ${ }^{9}$ : nie dochodzi on do zrozumienia ogromnego dystansu, który mógł istnieć między ideologią prześladowanych a rzeczywistością. „Chrześcijanie - pisze niemiecki profesor - mogli uskarżać się na bycie niczym łowna zwierzyna, co nie było sytuacją codzienną. Mogli oni uważać się za przykłady heroizmu, podczas gdy nieczęsto byli w stanie go dowieść". Zwracam szczególną uwagę na zakończenie zdania: „Umieszczali siebie samych ponad wielkimi tego świata i w rzeczywistości zawsze się doń dostosowywali" ${ }^{10}$.

Jest coś na pierwszy rzut oka paradoksalnego w sytuacji Kościoła, zrzeszającego wiernych z wyższych klas, zobligowanych do życia pełnego wyrzeczeń, a jednocześnie zdolnego utrzymywać ideologię rozłamu. Napisy z katakumb Pryscylli wskazują nam „wieczność wiary w licznych pokoleniach rodu Acyliuszy, wśród których znajdowali się nie tylko konsule i członkowie magistratu najwyższego rzędu, lecz także kapłani, kapłanki, a nawet dzieci, uczęszczające do znamienitych szkół, do których przynależność stanowiła przywilej zarezerwowany dla patrycjuszy i ich synów"11. Jeśli

\footnotetext{
E. Renan, Église chrétienne, Paris 1879, s. 137.

P. Allard, Dix leçons..., s. 137.

Tenże, M. Harnack et le nombre de martyrs, „Revue des Questions Historiques”, lipiec 1905, s. 235-246.

P. Allard, Dix leçons..., s. 142. Por. moje rozważania w: Le système historique de Renan, Paris 1906, s. 312-315.

Tamże, s. 206.
} 
wyznawanie ideologii chrześcijańskiej byłoby ściśle determinowane przez status materialny, taki paradoks nie byłby możliwy.

Statystyki dotyczące prześladowań nie odgrywają u zatem istotnej roli. Szczególne okoliczności, jakie towarzyszyły scenom męczeństwa, mają dużo większe znaczenie niż ich częstotliwość. To właśnie z powodu zajść dość rzadkich, jednak niezwykle heroicznych, powstała ideologia: męczenników nie musiało być wielu, by poprzez czyny dowieść absolutnej prawdziwości nowej religii oraz absolutnego błędu dawnych; by dowieść także, że istniały dwie niespójne względem siebie drogi, oraz by wyjaśnić, że panowanie zła ma swój koniec. „Możemy - mówi Harnack - mimo niewielkiej liczby męczenników ocenić, jakiej odwagi wymagało stanie się chrześcijaninem i życie wedle chrześcijańskich zasad. Należy przede wszystkim zrozumieć postawę męczennika, którego jedno słowo lub gest mogły uczynić niewinnym, lecz który wolał śmierć od bezkarności" ${ }^{12}$. Współcześni, widzący w męczenniku dowód sądowy, stanowiący świadectwo chwały Chrystusa ${ }^{13}$, wysnuwali z jego cierpienia wnioski zupełnie inne niż te, które mógłby sformułować współczesny historyk, rozumujący wedle współczesnych zasad. Ideologia nigdy nie była tak daleka od faktów, jak w tym przypadku.

Rzymska administracja niezwykle surowo traktowała tych, którzy wydawali się winni zakłócania porządku publicznego, a zwłaszcza wszystkich oskarżanych o znieważenie cezara. Ten, uderzając co jakiś czas w chrześcijan, których mu zadenuncjowano (z powodów, które dziś na ogół pozostają nieznane), nie zdawał sobie sprawy z popełniania czynu, który miał zapaść w pamięć potomności. Wydaje się, że społeczeństwo nie przywiązywało do problemu chrześcijan większej wagi, co wyjaśnia, dlaczego prześladowania nie zostawiły niemal żadnych śladów w literaturze świeckiej. Poganie nie widzieli powodów, by przypisywać męczeństwu chrześcijan szczególne znaczenie, jakie miało ono dla samych chrześcijan oraz ich sympatyków.

Ideologia ta $\mathrm{z}$ pewnością nie ukształtowałaby się $\mathrm{w}$ tak paradoksalny sposób, jeśli nie wierzylibyśmy ślepo w tragedie opisywane przez liczne apokalipsy stworzone pod koniec I wieku i na początku wieku II. Byliśmy przekonani, że świat przeszedł pod panowanie sił zła i że Chrystus przyjdzie, by zapewnić ostateczne zwycięstwo swym wybrańcom. Każdy przypadek prześladowań wzbogacał mitologię Antychrysta o nową, straszliwie dramatyczną cechę. Nie doceniono jego - zła uderzającego jednostki, lekcji dla społeczności czy tymczasowych pęt, nałożonych przez propagandę - wagi, stał się on elementem wojny, toczonej przez Szatana, księcia świata, który wkrótce zamierzał objawić swego Antychrysta. Tak oto rozłam się pogłębiał, a wraz

Tamże, s. 142.

G. Sorel, Le système historique..., s. 335-336. 
z nim prześladowania i gorączkowe oczekiwanie na decydującą bitwę. Gdy chrześcijaństwo wystarczająco się rozwinęło, literatura apokaliptyczna przestała być kultywowana, jednakże idea leżąca u jej podstaw nie przestawała oddziaływać. Akty męczeństwa opisywano w sposób mający wywołać uczucia wiodące do apokalipsy; można nawet rzec, iż je zastępowały ${ }^{14}$ : niejednokrotnie w literaturze prześladowań można odnaleźć opis, równie czytelny, jak w apokalipsach, koszmaru, jakiego doświadczali wierni ze strony ścigających ich wysłanników Szatana ${ }^{15}$.

Możemy zatem uznać, że socjalizm jest doskonale rewolucyjny; mimo że wywołuje jedynie krótkie i nieliczne konflikty, mają one potencjał, by zjednoczyć w imię idei strajku generalnego. Wszystkie wydarzenia przyjmą zatem zwielokrotnioną formę i, o ile język katastroficzny zostanie utrzymany, rozłam stanie się doskonały. Tak oto można oddalić główny zarzut stawiany rewolucjonistom: cywilizacja absolutnie nie jest zagrożona upadkiem wskutek eskalacji brutalności, jako że idea strajku generalnego pozwala klasyfikować pod pojęciem walki klas wypadki, które wydają się nieszczególnie istotne z punktu widzenia burżuazyjnych historyków.

Kiedy klasy rządzące, niemające odwagi, by dłużej sprawować władzę, pełne wstydu z powodu ich uprzywilejowanej sytuacji, zdecydują się poczynić awanse w stronę wrogów, ogłaszając swą całkowitą winę za rozłam w społeczeństwie, dużo trudniejsze stanie się utrzymanie pośród proletariatu idei rozłamu, bez którego niemożliwe byłoby odegranie przez socjalizm jego historycznej roli. Tym lepiej - stwierdzą odważni. Możemy więc mieć nadzieję, że przyszłość świata nie zostanie powierzona prostakom, nieszanującym nawet państwa, którzy kpią z wyższych ideologii burżuazji i nie żywią już podziwu dla myślicieli ani dla duchownych. Czyńmy więc każdego dnia więcej dla wydziedziczonych - mówią ci ichmoście. Pokażmy się jako lepsi chrześcijanie, lepsi filantropi, lepsi demokraci (wedle temperamentu każdego z nas); zjednoczmy się w celu wypełnienia społecznego obowiązku. Zyskamy w ten sposób owych strasznych socjalistów, wierzących w możliwość obalenia prestiżu intelektualistów po tym, jak ci obalili prestiż Kościoła. W istocie te moralne i uczone rozmyślania spełzły na niczym, czego przyczynę nietrudno dostrzec.

Piękne rozumowanie owych panów, kapłanów społecznego obowiąz$\mathrm{ku}$, nie bierze pod uwagę tego, że przemoc mogłaby się rozwinąc lub zanik-

14 Jest możliwe, że pierwsze pokolenie chrześcijan nie posiadało wystarczającej wiedzy, by zamienić akty męczeństwa na apokalipsy z literatury żydowskiej; to wyjaśniałoby, dlaczego nie dysponujemy praktycznie żadnym cytatem starszym niż datowany na rok 155 (list Smyrneńczyków opisujący śmierć św. Polikarpa) i dlaczego określona liczba starożytnych męczenników rzymskich mogła zostać stracona.

15 E. Renan, Marc-Aurèle et la fin du monde antique, Paris 1882, s. 500. 
nąć w miarę wypowiadania większej liczby komunałów oraz czynienia więcej uprzejmości i umizgów przez intelektualistów, a wszystko to na rzecz zjednoczenia klas. Na nieszczęście tychże wielkich myślicieli sprawy potoczyły się zgoła inaczej. Okazuje się, że poziom przemocy nie przestaje wzrastać, podczas gdy - wedle wskazań wyższej socjologii - powinien spadać. Istnieją zatem w rezultacie nieszczęśni socjaliści, korzystający z nikczemności burżuazji po to, by wciągnąć tłumy do ruchu, z każdym dniem coraz mniej przypominającego ten, który miałby stanowić wynik poświęceń poczynionych przez burżuazję na rzecz pokoju. Niewiele brakuje, by socjologowie ogłosili, że socjaliści szachrują, dopuszczając się nieprawomyślnych czynów - tak bardzo fakty różnią się od ich przewidywań.

Nietrudno było tymczasem zrozumieć, że socjaliści nie pozwolą się pokonać bez wykorzystania wszelkich środków, mogących obrócić sytuację na ich korzyść. Osoby, które poświęciły swe życie jednej sprawie, równoważnej dla nich z odnową świata, nie mogły wahać się przed wykorzystaniem wszelkich środków, by rozbudzić tym więcej ducha walki klasowej, im większe wysiłki podejmowano, by go zniweczyć. Istniejące stosunki społeczne sprowadziły się do nieskończonej wielości aktów przemocy. Nie omieszkano także zaangażować robotników, by nie ulec przemocy, skoro jej obecność mogła okazać się pomyślna. Burżuazyjni filantropi wyprawiali przyjęcia dla związkowców, skłonnych zgodzić się na dyskusje, w nadziei, że owi robotnicy, dumni $z$ wizyt $\mathrm{u}$ arystokracji, udzielą swym towarzyszom rad na rzecz utrzymania pokoju. W tej sytuacji podejrzani o zdradę przeciwko zwolennikom reform społecznych musieli narodzić się dość szybko. Ostatecznie, i jest to fakt najbardziej godny zauważenia w całej powyższej historii, antypatriotyzm staje się zasadniczym elementem programu syndykalistów ${ }^{16}$.

Wprowadzenie antypatriotyzmu do ruchu robotniczego jest tym bardziej zauważalne, że wydarzyło się w momencie, w którym rząd wprowadzał w czyn teorie solidaryzmu. Léon Bourgeois czynił zbyteczne umizgi w stronę proletariatu, na próżno zapewniał, że społeczeństwo kapitalistyczne to wielka rodzina i że biedak może uwierzyć w powszechne bogactwo. Utrzymywał, że ogół współczesnego prawodawstwa zwraca się ku rozwiązaniom solidarystycznym. Proletariat odpowiadał, zaprzeczając w sposób jak najbardziej grubiański, paktowi społecznemu, negując patriotyczny obowiązek. W chwi-

16 Niczym my, którzy opisujemy wszystko z historycznego punktu widzenia. Nie jest szczególnie istotne, by znać powody, jakimi kierowali się pierwsi apostołowie antypatriotyzmu; powody tego rodzaju prawie nigdy nie są dobre. Najważniejsze, by dla robotnikówrewolucjonistów antypatriotyzm wydawał się nieodłączny od syndykalizmu. 
li, w której wydawało się, że znaleziono środek zniesienia walki klasowej, oto jak ta zapanował, przybierając formę szczególnie nieprzyjemną ${ }^{17}$.

Tak oto, ku rozpaczy socjologii, wszyscy odważni osiągnęli skutki całkowicie sprzeczne z ich wysiłkami. Jeśli zachowaliby zdrowy rozsądek (fr. sens commun, ang. common sense) i gdyby naprawdę pragnęli chronić społeczeństwo przed nagromadzeniem przemocy, nie doprowadziliby socjalistów do konieczności przyjęcia taktyki, która do dziś nad nimi ciąży. Pozostaliby spokojni, zamiast poświęcać się na rzecz społecznego obowiązku; błogosławiliby głosicieli strajku generalnego, w istocie pracujących, by zaprowadzić spójny socjalizm przy najmniejszym możliwym wykorzystaniu przemocy. Jednakże odważni nie zachowali rozsądku. Powinni oni znosić jeszcze więcej ciosów, więcej upokorzeń i więcej finansowych strat, zanim zdecydowaliby się na to, by socjalizm nadal trwał.

\section{II}

Pogłębimy teraz nasze studia i zadamy sobie pytanie, na jakich motywach zasadza się głęboka niechęć, którą ukazują nam moraliści, kiedy bezpośrednio stykają się z aktami przemocy. Zwięzła enumeracja kilku niezmiernie ciekawych zmian, jakie zaszły w obyczajach klasy robotniczej, jest na początek niezbędna.

A. Obserwuję przede wszystkim, że nic nie jest bardziej zauważalne niż zmiana, która zaszła w sposobie wychowywania dzieci. Niegdyś uznawaliśmy, że rózga stanowiła najbardziej użyteczne narzędzie dyrektora szkoły; dziś kary cielesne zniknęły ze szkolnictwa publicznego. Wierzę, że sprzeciw wobec nauczania kościelnego miał ogromne znaczenie dla tegoż postępu. Ojcowie z niezwykłym rygorem stosowali dawne zasady klerykalnej pedagogiki, polegającej - jak wiemy - na wielu razach i nadmiernym karaniu, mającym na celu poskromienie demona, skłaniającego dziecko do wyrabiania złych przyzwyczajen ${ }^{18}$. Władza okazała się wystarczająco bystra, by przeciwstawić tej barbarzyńskiej edukacji nauczanie łagodniejsze, zjednujące jej wiele sympatii. Dotkliwość kar nakładanych przez duchownych bez wątpienia na niewiele się zdała, gdy wybuchły akty nienawiści, z którymi tak mozolnie zmaga się Kościół. W roku 1901 pisałem: „Jeśli [Kościół] byłby zdolny do refleksji, zniszczyłby wszystkie dzieła poświęcone dzieciństwu; zamknąłby szkoły i warsztaty - zniweczyłby tym samym główne źródło antyklerykalizmu. Jest on jednak daleki od wkroczenia na tę drogę i wydaje się chcieć co-

Propaganda ta wywołała skutki, które znacznie przekroczyły oczekiwania swych promotorów i które nie dają się wyjaśnić za pomocą idei rewolucyjnej.

18 Por. E. Renan, Histoire du peuple d'Israël, t. IV, Paris 1887-1893, s. 289, 296; Y. Guyot, La Morale, Paris 1883, s. 212-215; rozdz. IV w: A. Daudet, Numa Roumestan, Paris 1881. 
raz bardziej rozwijać owe instytucje, przez co nadal zapewnia piękne czasy dla nienawiści ludu do kleru" ${ }^{\prime 1}$. To, co stało się od 1901 roku, przekracza jeszcze moje przewidywania.

Niegdyś w fabrykach istniały obyczaje odznaczające się wielką brutalnością. Działo się tak szczególnie tam, gdzie wskutek konieczności zatrudniano mężczyzn o wielkiej sile, których nazwano „grosses culottes”. Ostatecznie powierzono im zadanie prowadzenia werbunku, gdyż „każda jednostka zwerbowana przez inną została poddana niekończącym się nieszczęściom i obelgom". Ci, którzy chcieli dostać się do ich warsztatu, musieli opłacić ich trunki, zaś nazajutrz należało ugościć także ich kamratów. „Słynne kiedy... działa. Każdy bierze swoją zapałkę. Owo kiedy... stanowi kondensator ekonomii. Do warsztatu, w którym istnieje zwyczaj kiedy..., należy wejść lub mieć się na baczności". Denis Poulot, za którym przytaczam powyższe szczegóły, zauważa, że maszyny zniweczyły prestiż les grosses culottes, nie będących niczym więcej, jak tylko wspomnieniem w chwili, kiedy o nich pisał, a było to w roku $1870^{20}$.

Obyczaje czeladników przez długi czas odznaczały się wyjątkowym okrucieństwem. Przed 1840 rokiem nieustannie wszczynano burdy, częstokroć krwawe, między grupami różnych zawodów. Martin Saint-Léon w swej książce o czeladnikach przytacza wypisy $\mathrm{z}$ iście barbarzyńskich piosenek ${ }^{21}$. Przyjęcia pełne były ciężkich prób, młodych traktowano jak pariasów w Devoirs de Jacques et de Soubise. „Widzieliśmy - opowiada Perdiguier - czeladników, aspirujących do wykonywania zawodu stolarza, nazywających siebie samych lisią zarazą, postrachem lisów... Na prowincji lisy rzadko pojawiają się w miastach - poluje się na nie w zaroślach" ${ }^{\prime 2}$. Liczne rozłamy zaistniały, odkąd tyrania czeladników znalazła się w opozycji do bardziej liberalnych obyczajów, dominujących w społeczeństwie. Kiedy robotnicy nie potrzebowali już protektora, szczególnie w kwestii znalezienia pracy, nie zgadzali się tak łatwo na przyjęcie wymagań, które niegdyś wydawały się mieć znikome znaczenie w porównaniu do korzyści płynących z terminowania. Okoliczności walki o pracę niejednokrotnie ujawniły kandydatów i czeladników, chcących zatrzymać przywileje ${ }^{23}$. Możemy znaleźć kolejne wyjaśnienia, tłuma-

G. Sorel, Essai sur l'Église et l'Etat, Paris 1901, s. 63.

D. Poulot, Le sublime, Paris 1887, s. 150-153. Autor ten twierdzi, że grosses culottes w istotny sposób zakłócili postęp w kuźniach.

M. Saint-Léon, Le compagnonnage, Paris 1901, s. 115, 125, 270-273, 277-278.

Tamże, s. 97. Por. tamże s. 91-92, 107.

W 1823 czeladnicy stolarscy, podający się za pochodzących z La Rochelle, które to miasto opuścili dawno temu jako zbyt niewiele znaczące, nie zatrzymali się wcześniej niż w Nantes i Bordeaux (M. Saint-Léon, Le compagnonnage, s. 103) - Związek Robotników Tour de France zawiązał się w opozycji do czeladników, istniał w latach 1830-1832, a powstał na 
czące upadek instytucji, która świadcząc poważne usługi, walnie przyczyniła się do utrzymania idei przemocy.

Cały świat ocenia, że zniknięcie dawnych aktów brutalności to rzecz doskonała. Zbyt łatwo było przejść od tej opinii do idei, wedle której każda przemoc stanowi zło, przy czym nie jest to opinia wyolbrzymiona. W efekcie masy, nieprzyzwyczajone do myślenia, doszły do tego wniosku, przyjmowanego dziś jako dogmat przez podążających za owczym pędem moralistów. Nie zadali sobie oni pytania, cóż tak nagannego jest w brutalności.

Jeśli nie chcemy się zadowolić pospolitą głupotą, spostrzegamy, że nasze idee, związane ze zniknięciem przemocy, w istotny sposób zależą od bardzo ważnej zmiany, która dokonała się w świecie przestępczym, a dotyczyła zasad etycznych. Oto, co spróbuję przedstawić.

B. Mędrcy burżuazji nie lubią zajmować się klasami niebezpieczny$\mathrm{mi}^{24}$ - to jeden z powodów, dla których wszelkie ich rozprawy odnośnie do historii obyczajów zawsze pozostają powierzchowne. Niezbyt trudno zauważyć, że to znajomość tychże klas pozwala zgłębić tajemnice myśli etycznej ludu.

W funkcjonujących dawniej grupach, stanowiących zagrożenie, popełniano najprostsze występki, a czynili to najlepsi ich członkowie - ci, którzy dziś wyznaczani są przez grupy młodych chuliganów bez doświadczenia i zdolności osądu. Brutalne zbrodnie wydają nam się dziś czymś anormalnym do tego stopnia, że jeśli natężenie przemocy jest ogromne, częstokroć pytamy siebie samych, czy winny korzystał ze swego zdrowego rozsądku. Zmiana ta oczywiście nie prowadzi do resocjalizacji, lecz do zmiany sposobu postępowania przestępców, zależnego od warunków ekonomicznych, jak zobaczymy to w dalszej części niniejszego wywodu. Wywarła ona największy wpływ na myśl ludową.

Wszyscy wiemy, że dzięki przemocy stowarzyszenia złoczyńców zdołały utrzymać w swym łonie doskonałą dyscyplinę. Kiedy widzimy złe traktowanie dziecka, instynktownie przypuszczamy, że jego rodzice mają obyczaje złoczyńców. Sposoby postępowania, przyjmowane przez dawnych dyrektorów szkół; sposoby, przy których uparcie trwają instytucje kościelne, to metody włóczęgów, porywających dzieci i przebierających je, by z nich uczynić zręcznych akrobatów lub zmyślnych żebraków. Wszystko, co przypomina obyczaje dawnych niebezpiecznych grup, jest dla nas w najwyższym stopniu nikczemne.

skutek niegroźnych protestów przeciwko reformom postulowanym przez tychże czeladników (tamże, s. 108-116, 126-131).

2430 marca $1906 \mathrm{r}$. Monis rzekł przed Senatem: „Nie możemy zapisać w tekście prawodawczym, że prostytucja we Francji dotyczy obu płci”. 
Dawne okrucieństwo było zastępowane przez podstęp. Wielu socjologów uznaje to za istotny postęp. Kilku filozofów, niepodążających za opinią tłumu, nie widzi jednak, co miałoby tu stanowić postęp z moralnego punktu widzenia: „Jeśli szokuje nas srogość, brutalność minionych czasów - mówi Hartmann - nie należy zapominać, że prawość, szczerość, żywe poczucie sprawiedliwości, nabożny szacunek do świętości obyczajów charakteryzuje dawne ludy, podczas gdy dziś widzimy raczej rządy łgarstwa, fałszu, perfidii, ducha matactwa, wzgardy dla własności, instynktownego lekceważenia uczciwości i prawych obyczajów, których wartość częstokroć nie jest już ro-

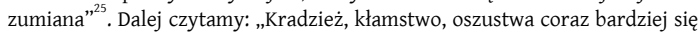
mnożą mimo represji nakładanych przez prawo. Nie zmniejszają one jednak liczby zbrodni ciężkich i okrutnych, takich jak rabunek, morderstwo, gwałt itd. Najniższy egoizm bezwstydnie plami święte miejsca rodziny i przyjaźni wszędzie tam, gdzie znajdzie się do nich w opozycji1" ${ }^{26}$.

Dziś na ogół uważamy, że straty pieniężne należą do wypadków, na które jesteśmy narażeni na każdym kroku i które łatwo naprawić, podczas gdy uszczerbku cielesnego nie rekompensuje się już tak łatwo. Uznajemy więc, że zastosowanie podstępu jest nieskończenie mniej dotkliwe niż brutalny występek. Przestępcy czerpią korzyści z tej zmiany, która dokonała się w sposobie osądzania.

Nasz kodeks karny został zredagowany w czasach, kiedy miano obywatela przyznawano na podstawie aktów właściciela ziemskiego - jedynej osoby, uprawnionej do zarządzania swą domeną, niczym dobry ojciec rodziny, tworzący swym dzieciom godne warunki. Wielkie fortuny zbite w interesach, poprzez politykę czy spekulacje były rzadko spotykane i postrzegane jako prawdziwe wynaturzenia. Ochrona oszczędności klas średnich stanowiła istotne zagadnienia dla prawodawców. Dawny reżim jeszcze okrutniej tępił oszustwa finansowe - królewski edykt z 5 sierpnia 1725 r. karał śmiercią defraudujących środki bankierów. Nie możemy wyobrazić sobie niczego, co bardziej odbiegałoby od naszych dzisiejszych obyczajów. Jesteśmy dziś skazani na wiarę $\mathrm{w}$ to, że wykroczenia tego rzędu nie mogłyby być popełnione inaczej jak tylko dzięki nieuwadze ofiar i że nie zasługują one, z niewieloma wyjątkami, na dotkliwe kary, zadowalamy się zaś karami łagodnymi.

W społeczeństwie bogatym, zajętym wielkimi sprawami, w którym każdy gorliwie broni swych interesów, jak dzieje się to wśród społeczeństwa

25 Hartmann kładzie tu nacisk na autorytet angielskiego naturalisty Wallace'a, gorąco wychwalającego obyczaje Malajczyków. Bez wątpienia jest w owych pochwałach pewna doza przesady, jednakże inni podróżnicy poczynili analogiczne obserwacje wśród plemion Sumatry. Hartmann chce wykazać, że nie istnieje postęp w stronę szczęścia, a to spostrzeżenie skłoniło go do wyolbrzymienia antycznej wizji szczęścia.

26 E. von Hartmann, Philosophie de l'Inconscient, Paris 1887, t. II, s. 464-465. 
amerykańskiego, występki oparte na podstępie w żadnym wypadku nie wywołują tych samych konsekwencji, jak dzieje się to w społeczeństwach zmuszonych do przestrzegania ścisłego reżimu finansowego. Nieczęsto zdarza się więc, by takie wykroczenia wywoływały głębokie i trwałe zakłócenia gospodarki - w ten oto sposób Amerykanie znoszą, nie skarżąc się zanadto, wybryki polityków i finansistów. P. de Roussiers porównuje Amerykanina do kapitana statku, który podczas nawigowania w trudnych warunkach nie ma czasu, by dopilnować okradającego go kucharza. „Kiedy powiemy Amerykanom, że politycy ich okradają, na ogół odpowiedzą: Dalibóg, dobrze o tym wiem! Dopóki sprawy jakoś się toczą, a politycy im nie zawadzają, uchodzą bez większego uszczerbku karze, na którą zasługują"27.

Odkąd łatwo zarobiliśmy majątek w Europie, idee podobne do amerykańskich rozprzestrzeniają się wśród nas. Wielcy spekulanci mogli ujść represjom, gdyż w czasie, gdy odnosili sukces, byli na tyle zręczni, by wytworzyć sobie liczne przyjaźnie w wielu kręgach. Uznaliśmy ostatecznie, że byłoby niesprawiedliwe oskarżać bankowych negocjatorów i notariuszy, którzy wycofali się, zrujnowani, po niewielkich katastrofach, podczas gdy książęta szalbierstwa wiodły radosny żywot. Nowa ekonomia stopniowo wywołała nieznane dotąd pobłażanie dla wszystkich podstępów w krajach rozwiniętego kapitalizmu ${ }^{28}$.

W krajach, w których przetrwała dawna gospodarka rodzinna, oszczędna i sroga wobec spekulacji, zgoda na akty przemocy i podstępu nie przeszła tych samych zmian, którym poddana została w Ameryce, Anglii czy Francji. W ten właśnie sposób Niemcy zachowały wiele dawnych zwyczajów ${ }^{2}$ i w żaden sposób nie odczuwają takiego koszmaru, jak my, należący do klas najbardziej zagrożonych.

Nie brakowało filozofów protestujących przeciwko takiemu złagodzeniu sądów. Wedle tego, co donosi Hartmann, jego samego należy szukać wśród protestujących: „Jesteśmy już - pisze - bliscy czasów, w których kradzież i matactwo, potępione przez prawo, będą uważane za wulgarne błędy, niczym grubiański zwrot, przez prawomyślnych rzezimieszków, nauczonych poszanowania dla treści prawa, przy naruszaniu praw innych. Ze swojego punktu widzenia zdecydowanie wolałbym żyć wśród dawnych Niemców, ryzykując utratę życia przy jakiejś okazji, niż we współczesnych miastach być zobowiązanym do postrzegania każdego człowieka jako oszusta czy łotra,

\footnotetext{
P. de Roussiers, La vie américaine: L'éducation..., s. 217.

Kilka małych krajów przyjęło te idee przez imitację, by znaleźć się na wysokości większych państw.

Należy podkreślić, że w Niemczech, w świecie spekulantów, jest tylu Żydów, że idee amerykańskie są tu trudno stosowalne. Spekulant jawi się powszechnie jako obcy, który tupi naród.
} 
o ile nie mam wystarczających powodów świadczących o jego niewinności ${ }^{\prime 30}$. Hartmann nie zdaje sobie sprawy z aspektu ekonomicznego, rozumuje z osobistego punktu widzenia i w żaden sposób nie ogląda się na to, co dzieje się wokół niego. Dzisiaj nikt nie chciałby być zagrożony możliwością poniesienia śmierci z rąk starożytnych Germanów, a łotrostwo czy kradzież nie stanowią nic więcej niż tylko łatwe do zrekompensowania szkody.

C. By w końcu dotrzeć do podstaw współczesnej myśli, należy zbadać, w jaki sposób społeczeństwo akceptuje relacje między państwem a zbrodniczymi stowarzyszeniami. Relacje te zawsze istniały; społeczeństwa, doświadczywszy przemocy, ostatecznie zaczęły praktykować podstęp, a przypadki stosowania tejże przemocy stały się raczej wyjątkowe.

Uznalibyśmy dziś za kuriozalne, jeśli członkowie magistratu stanęliby na czele uzbrojonych grup, jak miało to miejsce w Rzymie w czasie ostatnich lat Republiki. W czasie procesu Zoli antysemici zwerbowali oddziały uzbrojonych manifestantów, zajmujących się wyrażaniem narodowego oburzenia. Rząd Méline’a bronił tychże działań, odnoszących przez kilka miesięcy sukces. Przyczyniły się one w istotny sposób do zakłócenia rzetelnej rewizji wyroku Dreyfusa.

Nie wydaje mi się, bym mylił się, twierdząc, że taka taktyka zwolenników Kościoła stanowiła pierwszą przyczynę wszelkich środków podjętych przeciwko katolicyzmowi od 1901 r.: liberalna burżuazja nigdy by ich nie zaakceptowała, gdyby nie była pod wrażeniem tego, co odczuwano podczas sprawy Dreyfusa. Istotny argument, którego Clemenceau użył, by podburzyć swych żołnierzy w walce przeciwko Kościołowi, oparty był na strachu - nie przestawał on oznajmiać niebezpieczeństwa, że frakcja rzymska nacierała na Republikę: prawa, dotyczące zgromadzeń, nauczania, organizacji Kościoła, stworzono, by uniemożliwić stronie katolickiej realizację walecznych zakusów, które ta wykazywała i które Anatole France tak często wyrzucał Lidze: oto prawa strachu. Liczni konserwatyści przyjęli to, co widzieli, z niesmakiem. Członków ruchu oporu porównywano do założycieli Kościoła; uznawano, że zaangażowanie grup bogobojnych złoczyńców musiało wrogo nastroić klasę średnią do ich sprawy ${ }^{31}$. Nie zdziwił nas widok Brunetière'a, będącego jednym ze zwolenników antydreyfusowskiej bandy, doradzającego poddanie się - to doświadczenie uzmysłowiło mu konsekwencje przemocy.

E. von Hartmann, Philosophie..., s. 465.

31 Na sesji rady miejskiej Paryża, datowanej na 26 marca 1906 r., prefekt policji stwierdził, że ruch oporu został zorganizowany przez komitet, mający siedzibę przy ulicy Richelieu 86, który opłacał bojówkarzy sumą 3-4 franków dziennie. Stwierdził również, że 52 paryskich księży obiecało albo ułatwić im działania, albo ograniczyć się do biernego oporu. Oskarżył on polityków katolickich o wspieranie kleru. 
Stowarzyszenia, których działania oparte są na podstępie, bez wątpienia nie wywołują takich reakcji wśród społeczeństwa. W czasach klerykalnej republiki Stowarzyszenie Saint Vincent de Paul było wspaniałym biurem nadzoru nad funkcjonariuszami każdego rzędu i stopnia, nie należy się więc dziwić, jeśli masoneria mogła świadczyć radykalnemu rządowi dokładnie takie same usługi, jakie filantropia katolicka świadczyła dawnym rządom. Nieodległa historia donosów niezwykle jasno wskazuje, jaki dokładnie punkt widzenia dominował w kraju.

Odkąd nacjonaliści weszli w posiadanie akt oficerów, zgromadzonych przez dygnitarzy Loży, wierzą, że nadszedł kres ich adwersarzy: panika, panująca przez kilka dni w obozie radykalnym, zdawała się potwierdzać ich przypuszczania. Wkrótce demokracja nie będzie niczym więcej, jak tylko szyderstwem dla tych, których nazywa się ludźmi małej cnoty - ludzi, donoszących na generała André i jego towarzyszy. Henry Bérenger w tych trudnych dniach wykaże, że doskonale zdawał sobie sprawę z moralności sobie współczesnych; nie zawaha się przed uznaniem tego, co nazwał „praworządnym nadzorem sprawowanym przez organizacje awangardy nad kastami kierującymi”; odkryje nikczemność rządu, który „zostawił, niczym donosicieli, tych, którzy uznali za ordynarny donos konieczność indagowania i denuncjowania przedstawicieli Kościoła rzymskiego” („Akcja”, 31 października 1904). Opatruje on rany nielicznych zwolenników Dreyfusa, którzy ośmielili się manifestować oburzenie. Postawa Josepha Reinacha wydawała mu się szczególnie skandaliczna - wydawało mu się, że tenże musiał czuć się niezmiernie zaszczycony byciem akceptowanym w Lidze na rzecz Praw Człowieka, która ostatecznie zdecydowała się prowadzić „słuszną walkę na rzecz obrony praw obywatela, zbyt długo poświęcanych na rzecz praw człowieka" („Akcja”, 22 października 1904). W końcu przegłosowano amnestię, by ogłosić niechęć dalszego wysłuchiwania wszystkich błahostek.

$\mathrm{Na}$ prowincji działało kilka grup partyzanckich ${ }^{32}$, lecz czy były one poważne...? Pozwalam sobie w to wątpić, gdy wczytuję się w akta opublikowane przez Péguya w dziewiątym numerze szóstej serii jego „Zeszytów Piętnastolecia”. Kilka majętnych osób, głośnych i chaotycznych, wydaje się zmieszanych w obliczu kpiących uśmiechów znaczących handlarzy i prominentnych aptekarzy, stanowiących elitę społeczeństw mądrych i muzykalnych, przed którymi zwykli perorować o Sprawiedliwości, Prawdzie i Świetle. Uosabiają oni potrzebę stania się stoikami.

Czy jest cokolwiek piękniejszego niż cytat z listu profesora Bouglé, wielkiego uczonego nauk społecznych, który znajduję na stronie 13: „Było

${ }^{32}$ Prowincja nie jest, tak jak Paryż, przyzwyczajona do pobłażania podstępom i zbójectwu. 
dla mnie wielkim szczęściem dowiedzieć się, że Liga zamierzała w końcu powiedzieć ostatnie słowo. Jej milczenie dziwiło i przerażało"? Oto chłopiec, któremu łatwo przychodzą tak zaskoczenie, jak strach. Francis de Pressensé również miał swoje lęki - jest w tym względzie specjalistą, lecz były one wyrafinowane, jak przystoi socjalistycznemu dżentelmenowi. Bał się, że demokracja stanie w obliczu nowej „suchej gilotyny”, podobnej do tej, która uczyniła tak wiele zła cnotliwym demokratom podczas skandali panamskich ${ }^{33}$. Kiedy widział, jak łatwo społeczeństwo przyjmuje współwinę rządu i stowarzyszenia dobroczynnego, przekształconego w przestępcze, kierował mściwe wyrzuty w stronę protestujących. Wśród najbardziej komicznych z nich należy wskazać politykującego pastora Saint-Étienne o nazwisku L. Comte. Pisał, w owym szczególnym języku, właściwym Lidze na rzecz Praw Człowieka: „Miałem nadzieję, że Sprawa ostatecznie zwalczy w nas moralną zarazę, na którą cierpimy i która oczyściła republikańskie sumienia z klerykalnego wirusa, którym przesiąkły. Na nic. Jesteśmy bardziej klerykalni niż kiedykolwiek" $^{\prime 34}$. W efekcie ów srogi człowiek pozostawał w Lidze. Logika protestancka i burżuazyjna! Nigdy nie możemy wiedzieć, czy Liga nie zdecydowałaby się świadczyć drobnych usług wspaniałym ministrom Świętej Ewangelii.

Nieco zbyt rozwlekle przedstawiłem owe groteskowe incydenty, jako że wydają mi się one właściwe, by scharakteryzować myśl moralną ludzi roszczących pretensje do kierowania nami. Osiągnięto w owym czasie to, że stowarzyszenia polityczno-kryminalne, funkcjonujące dzięki podstępowi, zajmują w dojrzałej demokracji niepoślednie miejsce. P. de Roussiers wierzy, że któregoś dnia Ameryka zdoła wyleczyć się ze zła, wynikającego z nikczemnych posunięć jej polityków. Ostrogorski, przeprowadziwszy długie i skrupulatne badanie "demokracji i organizacji partii politycznych", wierzy, że znalazł rozwiązania, które pozwolą nowoczesnym państwom wyzwolić się z wyzysku i ucisku, jaki wywierają na nie partie polityczne. Oto ślady platonizmu - żadne doświadczenie historyczne nie pozwala przypuszczać, że w kraju kapitalistycznym moglibyśmy powołać do życia demokrację bez przestępczych nadużyć, które dziś stwierdzamy wszędzie. Odkąd Rousseau pytał, czy demokracja nie zniosłaby w swym łonie żadnego partykularnego stowarzyszenia, rozumował, opierając się na wiedzy o średniowiecznych republikach. Znał historię lepiej niż jemu współcześni i uderzyła go ogromna rola, którą odgrywały stowarzyszenia polityczno-przestępcze. Uznał on za

33 Cahiers de quinzaine, $9^{\text {th }}$ serii VI, 1905, s. 9. F. de Pressensé był w czasie Panamy pierwszym subiektem Hébrarda. Wiemy, że ten był jednym z głównych beneficjentów grabieży panamskiej. Nie zniesławiło go to przed srogimi hugenotami. Czas nadal jest wyrocznią rozumnej demokracji i ministrów Świętej Ewangelii.

Tamże, s. 13. 
niemożliwe pogodzenie rozumu w demokracji z istnieniem takich sił, lecz doświadczenie uczy nas, że nie istnieją środki, by je zniweczyć ${ }^{35}$.

\section{Od Sokratesa do Lenina. Georges Sorel i problematyka przemocy w polityce}

W ypada zgodzić się z uwagą poczynioną przez Gwidona Zelejkę, że „od czasów Heraklita, który w wojnie widział główną siłę wprawiającą świat $\mathrm{w}$ ruch, zjawisko przemocy pojawiało się nieustannie w polu filozoficznej refleksji [...] Dopiero Georges Sorel uczynił z przemocy centralną kategorię filozoficznego namysłu nad społeczeństwem i dziejami. Jego kontrowersyjne tezy ujawniły $\mathrm{z}$ całą ostrością wagę i miejsce problemu" ${ }^{36}$. Uderzające jest jednak, że w Polsce myśl Sorela, szczególnie współcześnie, nie cieszy się zainteresowaniem, zarówno na niwie stricte naukowej, jak i w ramach szerzej zakrojonych dyskusji nad kwestiami społecznopolitycznymi (np. ruch alterglobalityczny). Zdecydowanie odmiennie sytuacja prezentowała się przed drugą wojną światową, a szczególnie za życia Sorela. Przed 1914 rokiem błyskawicznie przekładano jego pisma na język polski $^{37}$, jego myśl zaś zalazła wtedy gorącego orędownika w osobie Stanisława Brzozowskiego $^{38}$; w dwudziestoleciu międzywojennym Kazimierz Wyka

\footnotetext{
Rousseau, stawiając pytanie w sposób abstrakcyjny, wydawał się natychmiast potępiać wszelkie stowarzyszenia i nasze rządy wydawały się przez długi czas opierać na jego autorytecie, by poddać swej władzy wszystkie przejawy stowarzyszania się obywateli.

W. Hanasz, G. Zalejko, Przemoc: między destrukcją a kreacją, [w:] Przemoc. W poszukiwaniu interpretacji, red. W. Hanasz, G. Zalejko, Toruń 1991, s. 7-8.

G. Sorel, Złudzenia postępu, przeł. E. Reiter, Kraków 1912; tenże, O sztuce, religii, filozofii, przeł. M. Rudnicki, Lwów 1913.

„[...] jest Sorel jedną z najwszechstronniejszych i najgłębiej pracujących głów nowoczesnych [...] Za każdym razem, gdy powracam do wielokrotnie już przestudyowanych książek Sorela, czuję się szczęśliwszym, coraz pełniej obejmuję i dostrzegam bezmiar pracy, dokonanej przez tego wielkiego myśliciela i głębokiego człowieka". S. Brzozowski, Legenda Młodej Polski. Studya o strukturze duszy kulturalnej, Lwów 1910. Zob. też: tenże, Pamiętnik, Warszawa 2000 .
} 